\title{
SiM
}

\section{Kentucky, Horse Capital of the World}

\section{By Ted Sloan}

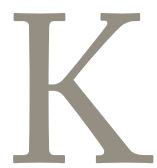

entucky and horses go together like a mint julep on the first Saturday in May. The Bluegrass State is home to thousands of horses of many breeds its claim as the Thoroughbred Capital of the World, and Shelby County, about 50 miles to the west, proclaims itself the Saddlebred Capital of the World.

"We love our horses here in Kentucky," Agriculture Commissioner Richie Farmer said. "They generate millions of dollars and some 80,000 jobs for the Commonwealth. They give us excitement and pleasure as we enjoy their speed and grace. They also give us companionship, whether it be on the racetrack, in the show ring, or on the riding trail. Horses are central to Kentucky culture."

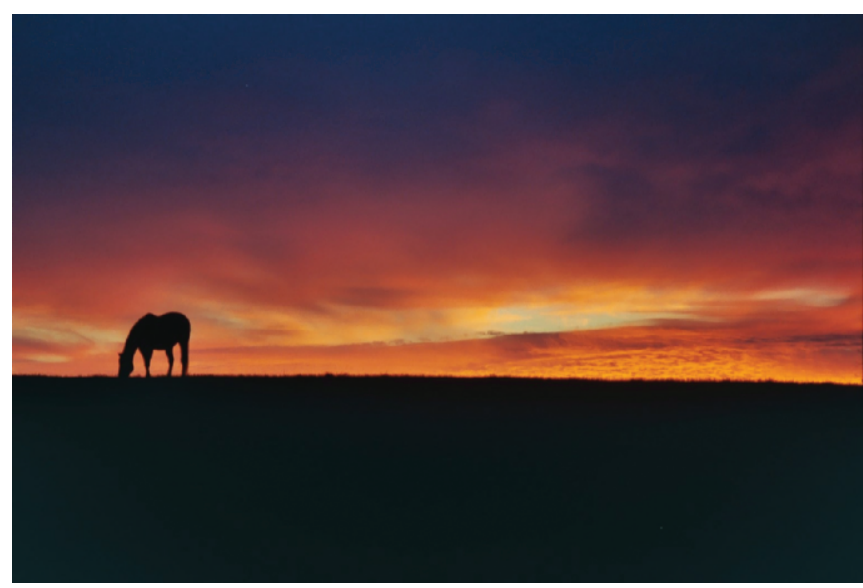

Horse at sunset in the Bluegrass region of Kentucky.
Horses accounted for more than $\$ 1$ billion of farmgate receipts in 2005, more than a quarter of Kentucky's total for the year, making them Kentucky's leading farm product. The thoroughbred industry generated most of that total. The region surrounding Lexington is dotted with some of the best-known horse farms in the world. Many of the regally bred foals from those farms are shipped to Lexington for the world-famous Keeneland sales, where horsemen from around the globe pay hundreds of millions of dollars for racing prospects. A precious few of the horses who pass through the sale ring at Keeneland will be reunited in

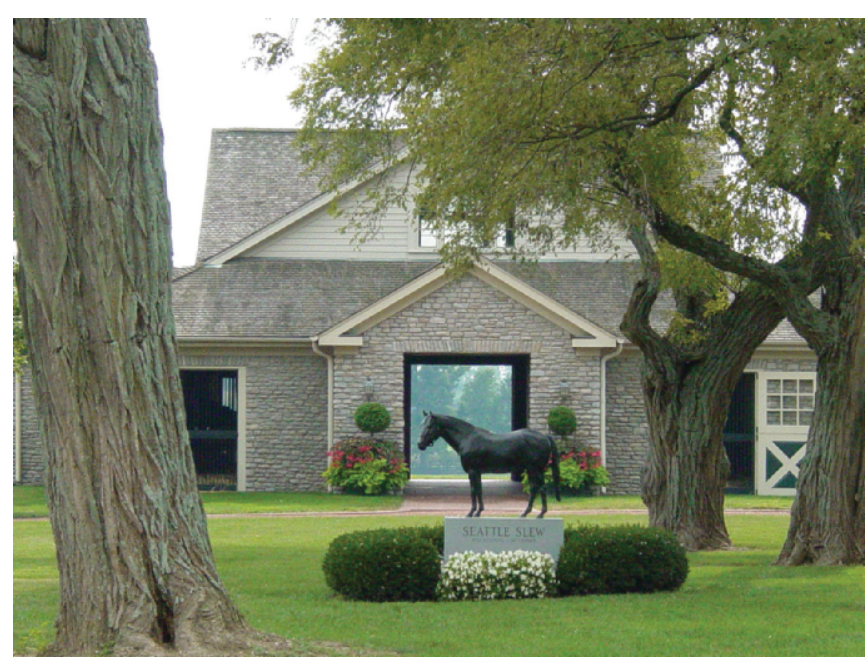

Seattle Slew monument at Three Chimneys Farm near Midway, Kentucky. 
Louisville for the Kentucky Derby and Kentucky Oaks on the first weekend in May.

Kentucky added a blue-chip event to its equine calendar when it was chosen to host the 2010 Alltech World Equestrian Games at the Kentucky Horse Park near Lexington. The Games are the world championship events for eight equestrian sports-show jumping, dressage, eventing, driving, reining, vaulting, endurance and paraequestrian. The 2010 Games will mark the first time the quadrennial event will be held outside Europe and in one venue. The 16-day event is expected to attract 600,000 people from around the world. The statewide economic impact of the Games is estimated at $\$ 150$ million.

The Kentucky Horse Park celebrates all things equine. It is the site of the International Museum of the Horse; the American Saddlebred Museum; the Hall of Champions, where some of the greats of the racetrack and show ring reside; and numerous other attractions. The Rolex Kentucky Three-Day Event, the only four-star three-day event in the Americas, tops a full schedule of equine competitions. The park offers tours, camping, and children's activities. More information is available at www.kyhorsepark.com.

Shelby County is the site of some of the leading Saddlebred breeding and training facilities in the world. The Shelbyville Horse Show, in the Shelby County seat, is a prep for the World's Championship Horse Show during the Kentucky State Fair in Louisville in August as well as a nationally known event in its own right.

Author is Information Officer, Division of Public Relations, Kentucky Department of Agriculture, 500 Mero St., 7th Floor, Frankfort, KY 40601, (502) 564-6676, ext. 247, ted.sloan@ ky.gov. 